\title{
Evaluation of the Coefficient of Thermal Expansion of Human and Bovine Dentin by Thermomechanical Analysis
}

\author{
Murilo Baena LOPES ${ }^{1}$ \\ Zhuoqun YAN ${ }^{2}$ \\ Simonides CONSANI ${ }^{3}$ \\ Alcides GONINI JÚNIOR ${ }^{1}$ \\ Anderson ALEIXO ${ }^{1}$ \\ John F. McCABE ${ }^{2}$
}

\author{
${ }^{1}$ Department of Dentistry, UNOPAR - University North of Paraná, Londrina, PR, Brazil \\ ${ }^{2}$ Dental Biomaterials, School of Dental Sciences, University of Newcastle, Newcastle upon Tyne, UK \\ ${ }^{3}$ Department of Restorative Dentistry, Piracicaba Dental School, \\ UNICAMP - University of Campinas, Piracicaba, SP, Brazil
}

\begin{abstract}
The mismatch of thermal expansion and contraction between restorative materials and tooth may cause stresses at their interface, which may lead to microleakage. The present work compared the coefficient of thermal expansion (CTE) with the thermomechanical behavior of human and bovine teeth and determined if the CTE is a suitable parameter to describe tooth behavior. Fifteen human third molar and 15 bovine incisor tooth slices $(6 \times 5 \times 2 \mathrm{~mm})$ were allocated to 3 groups according to the test environment: G1 - room condition, G2 - 100\% humidity, G3 - desiccated and tested in dry condition. Each specimen was weighed, heated from 20 to $70^{\circ} \mathrm{C}$ at $10^{\circ} \mathrm{C} \mathrm{min}{ }^{-1}$ and reweighed. The CTE was measured between 20 and $50^{\circ} \mathrm{C}$. Fresh dentin (human $-0.49 \% \pm 0.27$, bovine $-0.22 \% \pm 0.16$ ) contracted on heating under dry condition. Under wet conditions, only human teeth $(-0.05 \% \pm 0.04)$ showed contraction (bovine $0.00 \% \pm 0.03)$ accompanied by a significantly lower $(\mathrm{p}<0.05)$ weight loss than in dry specimens (human $0.35 \% \pm 0.15$, bovine $0.45 \% \pm 0.20)$. The desiccated dentin expanded on heating without obvious weight changes $(0.00 \% \pm 0.00)$. The CTE found was, respectively, in dry, wet and dissected conditions in ${ }^{\circ} \mathrm{C}^{-1}$ : human $\left(-66.03 \times 10^{-6},-6.82 \times 10^{-6}, 5.52 \times 10^{-6}\right)$ and bovine $\left(-33.71 \times 10^{-6}, 5.47 \times 10^{-6}, 4.31 \times 10^{-6}\right)$. According to its wet condition, the dentin showed different CTEs. The thermal expansion behavior of human and bovine dentin was similar. A simple evaluation of the thermal expansion behavior of tooth structure by its CTE value may not be appropriate as a meaningful consideration of the effects on the tooth-material interface.
\end{abstract}

Key Words: dentin, thermal diffusion, physical properties, coefficient of thermal expansion, bovine teeth, human teeth.

\section{INTRODUCTION}

Knowledge of canal morphology (1) and its structure is a basic requirement for endodontic treatment. Wide temperature fluctuations may occur in the oral environment due to the consumption of hot or cold food and fluids. Therefore, restorative materials placed in this environment may show thermal expansion or contraction in response to thermal stimuli. The mismatch of thermal expansion and contraction between a restoration and the tooth structure may cause stresses to develop at the interface of these two materials, which may have unfavorable effects on the margins and eventually lead to microleakage (2). Thus, deep knowledge of these structures is essential for understanding the permeability of this tissue, and therefore the efficacy of currently used intracanal medications and endodontic sealers (3-5).

The coefficient of thermal expansion (CTE) is normally used to describe the fractional dimensional changes of a substance in response to thermal stimuli. The evaluation of the CTE for tooth structure and restorative materials $(6,7)$ has shown that the CTE of enamel is around $11.4 \times 10^{-60} \mathrm{C}^{-1}$ and dentin around 8.0 $\times 10^{-6 \circ} \mathrm{C}^{-1}$, while the CTE for restorative materials is

Correspondence: Prof. Dr. Murilo Baena Lopes, Rua Marselha, 183, 86041-100 Londrina, PR, Brasil. Tel: +55-43-3371-7820. e-mail: baenalopes@gmail.com 
different, such as resin composite materials with a CTE of $17-50 \times 10^{-6}{ }^{\circ} \mathrm{C}^{-1}(8-10)$. Comparison of CTE between restorative materials and tooth structure has often been used to evaluate the microleakage potential resulting from thermal expansion and contraction $(8,11)$. There are also no references in the literature to measurements of thermal expansion in a wet environment, although there are some studies where the specimens were immersed in water (12).

Several in vitro studies have been carried out using extracted human teeth, which are sometimes difficult to obtain for various reasons $(13,14)$. Therefore, it has become necessary to consider alternative substrates, which makes bovine teeth an alternative. The size and availability of bovine incisors make them potentially useful $(15,16)$. However, there is some concern about whether data obtained from bovine teeth can be applied to human teeth and therefore about the validity of the results obtained from them in a clinical situation $(16,17)$.

The present study compared the CTE with the thermomechanical behavior of human and bovine teeth to verify if a simple CTE value can describe the behavior of real teeth. The null hypotheses to be tested are: 1 there is no difference in the thermal expansion behavior of human and bovine dentin in dry and wet conditions; 2 - the CTE is not a suitable parameter to describe the behavior of teeth.

\section{MATERIAL AND METHODS}

Fifteen human third molar and 15 bovine incisor

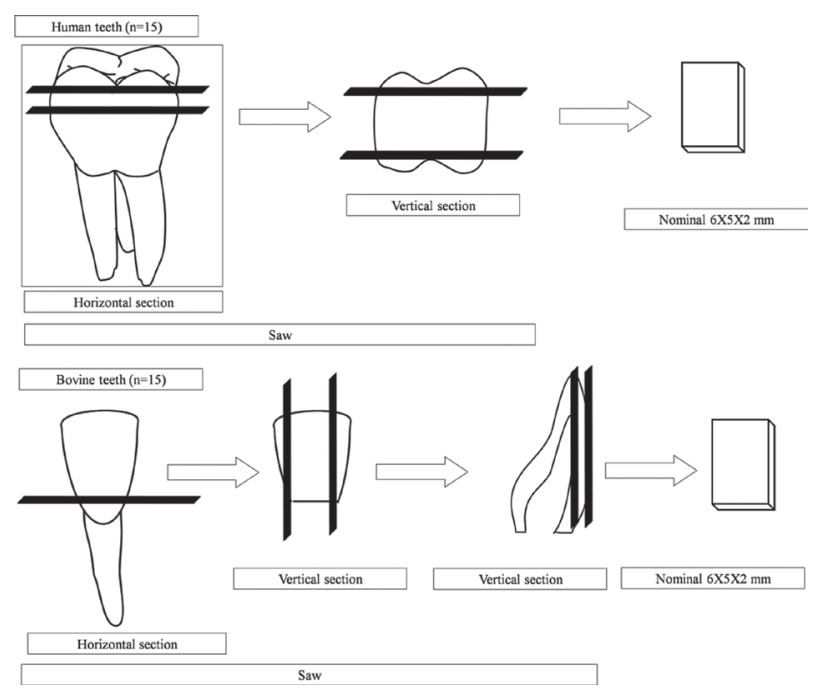

Figure 1. Sectioning of human and bovine tooth. dentin slices (nominal $6 \times 5 \times 2 \mathrm{~mm}$ ) were cut with a saw (model 650; South Bay Tech., San Clemente, CA, USA) from freshly extracted teeth (Fig. 1) and allocated to 3 groups (G1, G2, G3). The thermal expansion behavior of G1 was determined at room conditions at $65 \%$ relative humidity and $20^{\circ} \mathrm{C}$ (Fig. 2). For G2, each specimen was surrounded by a thin layer of damp cotton with the top and bottom surfaces of the specimen left uncovered (Fig. 2). Distilled water was syringed onto the cotton before the specimen was tested. This ensured that these specimens were tested under wet conditions $(100 \%$ humidity). A pilot study using composite specimens was previously done to validate the method and to ensure the $100 \%$ humidity method was fully functional. G3 was stored in a desiccator at $100^{\circ} \mathrm{C}$ for 3 days and had the weight measured ( $\mathrm{e}=0.001 \mathrm{~g}$, model AG200; Indústria e Comércio Eletro Eletrônica Gehaka Ltda., São Paulo, SP, Brazil) every $12 \mathrm{~h}$. After 3 consecutive measures without obvious changes $( \pm 0.02 \mathrm{~g})$, the specimens were considered dry and were immediately tested (Fig. 2).

The thermal expansion properties were determined by a thermomechanical analyzer (Stanton Redcroft, London, UK). Each sample was held vertically in the holding chamber with an optically flat base. A quartz probe, controlled by a balanced beam, with constant but negligible load (approximately $1 \mathrm{~g}$ ) was placed on the sample. Adisplacement transducer was connected to the probe to detect the dimensional change of the sample. Each specimen was weighed, heated from 20 to $70^{\circ} \mathrm{C}$ at $10^{\circ} \mathrm{C} \mathrm{m^{-1 }}$ and then reweighed. To determine the coefficient of thermal expansion, the considered change in temperature was from 20 to $50^{\circ} \mathrm{C}$. Data from weight change and thermomechanical analyzer were subjected to ANOVA and Tukey's test at 5\% level of significance.

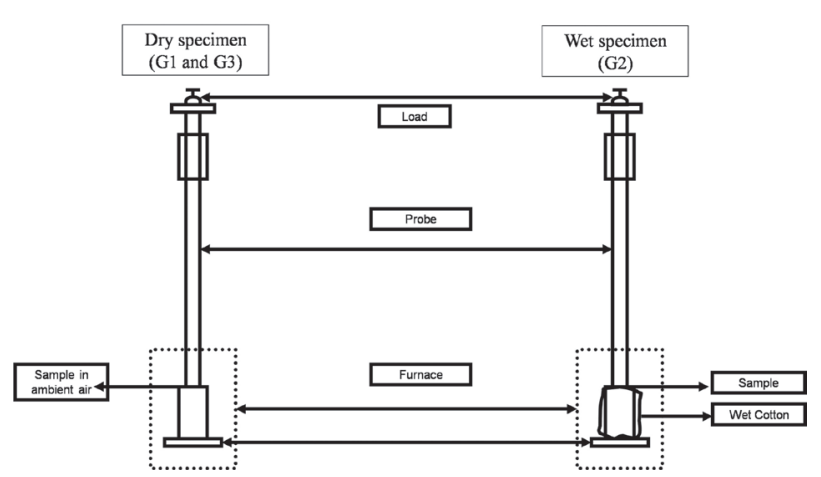

Figure 2. Specimen inside the thermomechanical analyzer. 


\section{RESULTS}

The results in percentage of dimensional and weight change and coefficient of thermal expansion (Table 1) were obtained. Fresh human and bovine dentin contracted on heating under dry condition. Under wet conditions, only human teeth showed contraction. The contraction was significantly greater under dry conditions $(\mathrm{p}<0.05)$. Contraction of human and bovine wet specimens was accompanied by a significantly lower $(\mathrm{p}<0.05)$ weight loss than in dry specimens. The desiccated dentin expanded on heating without obvious weight changes.

\section{DISCUSSION}

The human tooth structure in the oral environment is affected by considerable thermal fluctuations while consuming hot and cold aliments. When a composite material, such as dentin, is subjected to a temperature change, the various constituents in its tend to expand by different amounts. This occurs mainly because of the presence of different materials having various coefficients of expansion or inhomogeneities in their microstructure (18). These incompatibilities can engender internal stresses and strains, while playing a dominant role in the creation of thermal fatigue damage, such as interfacial debonding and microcracking at elevated temperatures (18).

It has been reported that a sudden thermal shock could occur in the mouth, thereby damaging dental pulp

Table 1. Percentage of dimensional (D) and weight (W) change for human and bovine dentin $\left(20\right.$ to $\left.70^{\circ} \mathrm{C}\right)$. Coefficient of thermal expansion $(\mathrm{CTE})$ in ${ }^{\circ} \mathrm{C}^{-1}$ of the tooth dentin crown (range $20-50^{\circ} \mathrm{C}$ ).

\begin{tabular}{lccc}
\hline Group & & Human dentin & Bovine dentin \\
\hline G1 & $\mathrm{D}$ & $0.49 \pm 0.27 \mathrm{~b}$ & $0.22 \pm 0.16 \mathrm{ab}$ \\
(Dry) & $\mathrm{W}$ & $1.87 \pm 0.67 \mathrm{~B}$ & $2.12 \pm 0.38 \mathrm{~B}$ \\
& $\mathrm{CTE}$ & $-66.03 \times 10^{-6}$ & $-33.71 \times 10^{-6}$ \\
G2 & $\mathrm{D}$ & $-0.05 \pm 0.04 \mathrm{a}$ & $0.00 \pm 0.03 \mathrm{a}$ \\
(Wet) & $\mathrm{W}$ & $0.35 \pm 0.15 \mathrm{~A}$ & $0.45 \pm 0.20 \mathrm{~A}$ \\
& $\mathrm{CTE}$ & $-6.82 \times 10^{-6}$ & $5.47 \times 10^{-6}$ \\
G3 & $\mathrm{D}$ & $0.02 \pm 0.01 \mathrm{a}$ & $0.01 \pm 0.02 \mathrm{a}$ \\
(Desiccated) & $\mathrm{W}$ & $0.00 \pm 0.00 \mathrm{~A}$ & $0.00 \pm 0.00 \mathrm{~A}$ \\
& $\mathrm{CTE}$ & $5.52 \times 10^{-6}$ & $4.31 \times 10^{-6}$ \\
\hline
\end{tabular}

Means followed by different lowercase or uppercase letters in the same property indicates a significant difference for Tukey's test (5\%). when ice $\left(0^{\circ} \mathrm{C}\right)$ or hot water $\left(60\right.$ to $\left.70^{\circ} \mathrm{C}\right)$ is placed in the mouth (19). The surface of a tooth can reach a critical temperature almost immediately after contact with heat sources, although the temperature rise is confined to the surface of the tooth for only a short time. After this sudden change, the oral temperature returns to normal via heat sinking resulting from circulating blood and/or saliva. This transient thermal effect has been reported to induce stress on the tooth and restorative materials (20). For endodontically compromised teeth, these temperature changes are even more critical due to the lack of pain sensitivity and circulating fluids inside the pulp chamber, which make the tooth more susceptible to higher temperature differences and return more slowly to the mouth temperature. Even though this stress may not be strong enough to fracture these materials immediately, it has been postulated that any microscopic flaws present at the tooth-restorative material interface may have a tendency to propagate slowly over many cycles of such stress and thereby produce microleakage at the interface (21).

The CTE of tooth structure is generally the reference against which the thermal expansion behavior of restorative materials is judged. However, the tooth structures are quite complex, producing complex and anisotropic properties (2). An in vitro study has shown that human dentin expands slightly on heating and contracts at higher temperatures (18). Furthermore, fluid flux in living tissue may also affect the thermal expansion behavior of dental structures; therefore, the behavior of tooth structures may be different in vivo and in vitro (2). This makes it difficult to assess the importance of thermally induced dimensional changes in restorative materials.

The CTE was calculated in the present study at the range of 20 to $50^{\circ} \mathrm{C}$ to compare the results with the literature findings $(9,10)$. The reference values for the CTE of dental materials always refers to the work of the National Bureau of Standards (9) and to a compilation of the results from that findings (10). The CTE for human teeth measured at near $100 \%$ relative humidity was $-6.82 \times 10^{-6}{ }^{\circ} \mathrm{C}^{-1}$ (Table 1) indicating a contraction with temperature rise. This probably occurred due to the expansion of the water molecules present within the dentinal tubules, moving the existing water out of the tubules. At the same conditions, bovine teeth showed a coefficient of $5.47 \times 10^{-6}{ }^{\circ} \mathrm{C}^{-1}$, indicating an expansion, which probably happened due to the larger dentinal tubules in the bovine teeth, making the capillary effect 
less efficient and reducing the water movement inside the tubules. For dry and desiccated conditions, human and bovine dentin showed similar behaviors.

The environment at near $100 \%$ humidity also contributed to the expansion by allowing little evaporation to occur. The results of the desiccated specimens tested in a dry environment showed a small expansion, indicating an influence of water in the obtained values for the specimens tested in a humid environment. If the clinical situation and the oral environment are considered, the specimens tested at near $100 \%$ relative humidity are closer to a real situation.

According to the results of the present work, the dentin did not expand or contract (Table 1) when the specimens were heated up to $70^{\circ} \mathrm{C}$, which is approximately the maximum temperature achieved in the mouth. These results do not agree with those of several previous studies $(6,11,12,20,22)$. However, the current study was the first one to test the thermal expansion under nearly $100 \%$ relative humidity. Previously, data were collected before immersion of specimens into water or placement of specimens in a dry environment (9). The lack of expansion of dentin could be due to the structure of dentinal tubules, which could absorb the expansion by moving tubular fluid. According to the data related to the lack of expansion of dentin, the difference of thermal expansion of restorative materials and dentin is much higher than what is actually believed. This is particularly important when developing restorative materials with as little thermal expansion as possible.

When fresh specimens were tested in a dry environment, a small contraction was found, probably due to the loss of water and organic substances, such as collagen, from the tooth. This could be confirmed by analyzing the data obtained from the percentage of weight change, where desiccated specimens did not show loss of material, which was a different result from the fresh.

Although human and bovine teeth have some different physical characteristics, such as tubule diameter (23), quantity of intertubular dentin $(17,23)$, dentin thickness (17), shape and enamel porosity $(24,25)$, the thermal expansion between these two substrates was found to be similar. These results validate using bovine teeth as a substitute for human teeth for in vitro studies and make the first null-hypothesis accepted. However, more studies have to be completed to verify other properties and characteristics. The second nullhypothesis in the current study must be rejected because the evaluation of the thermal expansion behavior of tooth structure by the CTE seems not to be representative of the effects on the tooth-material interface.

In conclusion, the thermal expansion behavior of human and bovine dentin in dry and wet conditions is not similar. A simple evaluation of the thermal expansion behavior of tooth structure by its CTE value may not be appropriate as a meaningful consideration of the effects on the tooth-restorative material interface.

\section{ACKNOWLEDGEMENTS}

Grateful acknowledgement is made to CAPES for its support in this research - BEX: 3427/04-8.

\section{RESUMO}

A discrepância entre a expansão e a contração térmica dos materiais restauradores e o dente podem causar estresse na sua interface, podendo levar a uma microinfiltração. O presente trabalho determinou e comparou o coeficiente de expansão térmica (CET) com o comportamento termo mecânico dos dentes humanos e bovinos e determinou se o CET é um parâmetro adequado para descrever o comportamento dental. 15 fatias $(6 \times 5 \times 2 \mathrm{~mm})$ de terceiros molares humanos e 15 de incisivos bovinos foram divididos em 3 grupos de acordo com o ambiente testado: G1 - condição ambiente, G2 - 100\% de umidade, G3 - dissecado e testado em condição seca. Cada espécime foi pesado, aquecido de 20 a $70^{\circ} \mathrm{C}$ a $10^{\circ} \mathrm{C} \min ^{-1}$ e pesados novamente. O CET foi mensurado entre 20 e $50^{\circ} \mathrm{C}$. Dentina fresca (humana $-0,49 \%$ $\pm 0,27$, bovina $-0,22 \% \pm 0,16$ ) contrai no aquecimento sobre condição seca. Em condição úmida, somente dente humano $(-0,05 \% \pm 0,04)$ mostrou contração (bovina $0,00 \% \pm 0,03)$ acompanhado por uma significante $(\mathrm{p}<0.05)$ perda de massa que os espécimes secos. Adentina dissecada expande no aquecimento sem mudanças óbvias de peso $(0,00 \% \pm 0,00)$. O CET encontrado foi, respectivamente, em condições seca, úmida e dissecada em ${ }^{\circ} \mathrm{C}^{-1}$ : humana $\left(-66,03 \times 10^{-6},-6,82 \times 10^{-6}, 5,52 \times 10^{-6}\right)$ e bovina $\left(-33,71 \times 10^{-6}, 5,47 \times 10^{-6}, 4,31 \times 10^{-6}\right)$. De acordo com sua condição de umidade, a dentina mostrou diferentes CETs. O comportamento de expansão térmica de dentes humanos e bovinos é similar. Uma simples avaliação do coeficiente de expansão térmica da estrutura dental pelo seu valor de CET pode não ser apropriada para uma consideração significativa dos efeitos na interface dente-material restaurador.

\section{REFERENCES}

1. Verma P, Love RM. A Micro CT study of the mesiobuccal root canal morphology of the maxillary first molar tooth. Int Endod J 2011;44:210-217.

2. Yan Z, Sidhu SK, Carrick TE, McCabe JF. Response to thermal stimuli of glass ionomer cements. Dent Mater 2007;23:597-600.

3. De Bruyne MA, De Bruyne RJ, De Moor RJ. Long-term assessment of the seal provided by root-end filling materials in large cavities through capillary flow porometry. Int Endod J 2006;39:493-501. 
4. De Bruyne MA, De Bruyne RJ, De Moor RJ. Capillary flow porometry to assess the seal provided by root-end filling materials in a standardized and reproducible way. J Endod 2006;32:206-209.

5. Camargo CH, Siviero M, Camargo SE, de Oliveira SH, Carvalho CA, Valera MC. Topographical, diametral, and quantitative analysis of dentin tubules in the root canals of human and bovine teeth. J Endod 2007;33:4226.

6. McCabe JF, Wassell RW. Thermal expansion of composites. J Mater Sci: Mater Med 1995;6:624-629.

7. Yamaguchi R, Powers JM, Dennison JB. Thermal expansion of visible-light-cured composite resins. Oper Dent 1989;14:64-67.

8. Craig RG, Powers JM. Restorative dental materials. 11th ed. St. Louis: Mosby 2002.

9. Souder WH, Peters GC. An investigation of the physical properties of dental materials. Dent Cosmos 1920;62:305-335.

10. Souder WH, Peters GC. Circular of the National Bureau of Standards C433: Physical properties of dental materials. Washington: U.S. Department of Commerce, National Bureau of Standards 1942.

11. Sidhu SK, Carrick TE, McCabe JF. Temperature mediated coefficient of dimensional change of dental tooth-colored restorative materials. Dent Mater 2004;20:435-440.

12. Xu HC, Liu WY, Wang T. Measurement of thermal expansion coefficient of human teeth. Aust Dent J 1989;34:530-535.

13. Almeida KG, Scheibe KG, Oliveira AE, Alves CM, Costa JF. Influence of human and bovine substrate on the microleakage of two adhesive systems. J Appl Oral Sci 2009;17:92-96.

14. Bajaj D, Sundaram N, Nazari A, Arola D. Age, dehydration and fatigue crack growth in dentin. Biomaterials 2006;27:2507-2517.

15. Burrow MF, Sano H, Nakajima M, Harada N, Tagami J. Bond strength to crown and root dentin. Am J Dent 1996;9:223-229.
16. Reeves GW, Fitchie JG, Hembree JH, Jr., Puckett AD Microleakage of new dentin bonding systems using human and bovine teeth. Oper Dent 1995;20:230-235.

17. Nakamichi I, Iwaku M, Fusayama T. Bovine teeth as possible substitutes in the adhesion test. J Dent Res 1983;62:1076-1081.

18. Kishen A, Asundi A. Investigations of thermal property gradients in the human dentine. J Biomed Mater Res 2001;55:121-130.

19. Brown WS, Dewey WA, Jacobs HR. Thermal properties of teeth. J Dent Res 1970;49:752-755.

20. Versluis A, Douglas WH, Sakaguchi RL. Thermal expansion coefficient of dental composites measured with strain gauges. Dent Mater 1996;12:290-294.

21. Bauer JRO, Reis A, Loguercio AD, Barroso LP, Grande RHM. Effects of aging methods on microleakage of an adhesive system used as a sealant on contaminated surfaces. J Appl Oral Sci 2005; 13:377-381.

22. Hashinger DT, Fairhurst CW. Thermal expansion and filler content of composite resins. J Prosthet Dent 1984;52:506-510.

23. Lopes MB, Sinhoreti MA, Correr Sobrinho L, Consani S. Comparative study of the dental substrate used in shear bond strength tests. Braz Oral Res 2003;17:171-175.

24. Edmunds DH, Whittaker DK, Green RM. Suitability of human, bovine, equine, and ovine tooth enamel for studies of artificial bacterial carious lesions. Caries Res 1988;22:327-336.

25. Turssi CP, Messias DF, Corona SM, Serra MC. Viability of using enamel and dentin from bovine origin as a substitute for human counterparts in an intraoral erosion model. Braz Dent J 2010;21:332-336. 